\title{
Shelf and estuarine transport mechanisms affecting the supply of competent larvae in a suite of brachyuran crabs with different life histories
}

\author{
A. O. Olaguer-Feliú ${ }^{1, *}$, A. A. V. Flores ${ }^{2}$, H. Queiroga ${ }^{3}$, J. I. González-Gordillo ${ }^{1}$ \\ ${ }^{1}$ CACYTMAR, Universidad de Cádiz, Campus Universitario de Puerto Real, 11510 Puerto Real (Cádiz), Spain \\ ${ }^{2}$ Centro de Biologia Marinha - Universidade de São Paulo, Rodovia Manoel Hipólito do Rego, km 131.5, 11600-000, \\ São Sebastião, São Paulo, Brazil \\ ${ }^{3}$ Departamento de Biologia, CESAM - Centro de Estudos do Ambiente e do Mar, Universidad de Aveiro, \\ 3810-193 Aveiro, Portugal
}

\begin{abstract}
Supply of competent larvae to the benthic habitat is a major determinant of population dynamics in coastal and estuarine invertebrates with an indirect life cycle. Larval delivery may depend not only on physical transport mechanisms, but also on larval behavior and physiological progress to the competent stage. Yet, the combined analysis of such factors has seldom been attempted. We used time-series analyses to examine tide- and wind-driven mechanisms responsible for the supply of crab megalopae to an estuarine river under a major marine influence in SW Spain, and monitored the vertical distribution of upstream moving megalopae, their net flux and competent state. The species Panopeus africanus (estuarine), Brachynotus sexdentatus (euryhaline) and Nepinnotheres pinnotheres (coastal) comprised $80 \%$ of the whole sample, and responded in a similar way to tide and wind forcing. Tidal range was positively correlated to supply, with maxima 0 to $1 \mathrm{~d}$ after spring tides, suggesting selective tidal stream transport. Despite being extensively subjected to upwelling, downwind drift under the effect of westerlies, not Ekman transport, explained residual supply variation at our sampling area. Once in the estuary, net flux and competence state matched the expected trends. Net upstream flux increased from $B$. sexdentatus to $P$. africanus, favoring transport to a sheltered coastal habitat ( $N$. pinnotheres), or to the upper estuary ( $P$. africanus). Competence state was highest in $N$. pinnotheres, intermediate in $B$. sexdentatus and lowest in $P$. africanus, as expected if larvae respond to cues from adequate benthic habitat. $P$. africanus megalopae were found close to the bottom, not above, rendering slower upstream transport than anticipated.
\end{abstract}

KEY WORDS: Upwelling - Ekman transport - Downwind drift - Selective tidal stream transport . Larval net flux · Bay of Cádiz

\section{INTRODUCTION}

A wide variety of life history strategies have evolved in marine and estuarine benthic invertebrates. Most coastal species undergo planktonic development, releasing a free-swimming pelagic propagule, which may be either retained close to the parental habitat or advected to the open ocean (Shanks 1995). Estuarine intertidal and benthic sub-tidal decapod crustaceans of- ten export their larvae to coastal or offshore waters (McConaugha 1988, Queiroga \& Blanton 2005); a strategy that probably favors the establishment of benthic populations in sink habitat patches and eventually contributes to the expansion of their geographical range. However, high vulnerability to starvation when in offshore waters (e.g. Lamare \& Barker 1999, Pechenik \& Levine 2007) and the chance of being transported too far from suitable habitats for settlement (Epifanio et al. 
1988, Palmer et al. 1996) makes dispersal neutral or even disadvantageous (Strathmann et al. 2002). An ontogenetic migration function has been hypothesized to better explain larval offshore exportation (Strathmann et al. 2002). Offshore migration of early life-cycle stages would reduce predation, expose larvae to a more tolerable environmental variability and, occasionally, diminish food competition with benthic suspension feeders in coastal or estuarine areas. Still, the migration back to adult habitats depends on how far the larvae migrate from the parental area, their behavioral capabilities and the water current patterns they are exposed to (Sponaugle et al. 2002).

As coastal (Caley et al. 1996, Armsworth 2002) and estuarine (Bilton et al. 2002) benthic populations may often be recruitment-limited, larval supply and settlement success are critical processes for their maintenance (Gaines \& Roughgarden 1985, Roughgarden et al. 1988). Understanding the mechanisms responsible for larval delivery to the parental habitat, and identifying the connectivity pathways that make sink populations viable are important tasks for the conservation of littoral marine resources.

Larval transport is mainly explained by the physical forcing of winds and tides because larval swimming is usually insufficient to countervail current speeds usually observed in the ocean and nearshore waters (Shanks 2006, Queiroga et al. 2007). In upwellingdominated coastlines, many studies have provided evidence of large-scale Ekman transport caused by longshore wind stress, mostly after the pioneering work of Roughgarden et al. (1988). In north-south oriented coasts, a large number of studies have suggested that larvae are carried offshore under the effect of upwelling-favorable winds, and onshore during the temporal windows when such wind forcing relaxes (e.g. Farrell et al. 1991, Connolly et al. 2001, Queiroga et al. 2006). However, recent work challenges this view. Numerical models (Marta-Almeida et al. 2006) and extensive larval sampling in shelf waters during intense upwelling conditions indicate that larvae may be retained close to the coast by maintaining their depth below the Ekman layer, where the prevalent flow is shoreward (Shanks \& Brink 2005, Morgan et al. 2009). A number of studies suggest that alternative processes may better explain temporal and spatial settlement patterns. For instance, cross-shore wind components, not longshore, apparently transport late larval stages of intertidal crabs to rocky areas of the Central Portuguese coast, suggesting that larvae follow a downwind path (Flores et al. 2002).

Besides the transport from shelf waters to the coast, late stage larvae of estuarine species necessarily undertake upstream migration toward appropriate habitat on which to settle (Shanks 1995). For this task, most planktonic larvae of invertebrates and fish conduct vertical migrations triggered by the strong vertical shear of salinity and hydrostatic pressure of tidal currents (reviewed by Forward \& Tankersley 2001). Salinity drops below that of average seawater have not only been detected in estuarine rivers, but over many coastlines due to coastal runoff. The extent to which coastal species, other than those that are strictly estuarine, benefit from such behavioral responses to achieve onshore transport is not well known.

As realistic measurements of the nearshore density of late stage larvae are difficult to obtain, temporal settlement patterns have been widely used to explain transport mechanisms over shelf and coastal waters (Farrell et al. 1991, Connolly et al. 2001, Rabalais et al. 1995). However, settlement may not be an adequate proxy of nearshore density of final larval stages (e.g. Incze \& Wahle 1991, Moreira et al. 2007, Rilov et al. 2008). Suitable settlement areas may be limited (Carr 1994, Eggleston \& Armstrong 1995) and larvae reaching the shore might fail to settle because of their physiological state (Basch \& Pearse 1996, Zeldis et al. 2005, Onitsuka et al. 2010). In estuarine systems, the competence state, vertical distribution and net flux of pelagic larvae, i.e. the difference between larvae moving upand downstream, may together largely explain the distribution patterns of benthic stages.

In this study, we first examine the effect of wind stress and tidal currents on the supply of late-stage larvae to an estuarine river, in an area where wind-driven upwelling is a common feature. As models, we used megalopae of 3 different species, whose adults exhibit strikingly different lifestyles and distributions, i.e. a coastal, a euryhaline and a strictly estuarine species. This allowed us to assess the generality of the model proposed and the likelihood of well-known, widely accepted transport mechanisms in our study system. As a second objective, we measured the vertical distribution of megalopae of the same 3 species, their net flux and competence state at an estuarine river, in order to evaluate their upstream migration potential. These joint results provided a starting point to address the relative role of pre- and post-settlement processes setting adult distribution patterns.

\section{MATERIALS AND METHODS}

Oceanography of the Gulf of Cádiz. The Gulf of Cádiz (GoC) is a wide basin located along the southwestern Iberian Peninsula, in the Atlantic Ocean, which is connected with the Mediterranean Sea through the Strait of Gibraltar. The surface circulation of the GoC is linked to the North Atlantic subtropical gyre formed by the Azores current, and, therefore, 
subjected to its seasonal fluctuations caused by the displacement of the Azores atmospheric high. However, an anticyclonic circulation within the Gulf occurs almost throughout the year (Vargas et al. 2003), but more markedly during spring and summer (GarcíaLafuente \& Ruiz 2007). Such large-scale circulation results in a SE longshore current following the coastline, from the northeastern shelf of the GoC to the Alborán Basin in the Mediterranean Sea (GarcíaLafuente et al. 2006).

There are, however, 2 cells of cyclonic circulation within the GoC. One is located over the western continental shelf and is affected by wind conditions generated around Cape São Vicente, Portugal, at the westernmost part of the Gulf (Relvas \& Barton 2002, Sánchez et al. 2006). The other cyclonic cell occurs on the eastern shelf and consists of a coastal warm water current, rich in nutrients, maintained by tidally driven buoyancy inputs from the Guadalquivir River and marshes near the Bay of Cádiz (García-Lafuente et al. 2006). Under the influence of easterly winds, the eastern cell is pushed westward, and both cells can be connected (Relvas \& Barton 2002). Westerlies, on the other hand, promote the recirculation of the eastern cell along the outer shelf, establishing a cyclonic circulation in the area (Relvas \& Barton 2002, García-Lafuente et al. 2006). These westerly winds prevail during the summer season in this area and induce remarkable coastal upwelling along the coast (Relvas \& Barton 2002, Criado-Aldeanueva et al. 2006, García-Lafuente et al. 2006), triggering broad biological activity. Therefore, easterlies favor oligotrophy and the westward export of plankton while westerly winds result in the confinement of planktonic yield within the cyclonic cell (García-Lafuente \& Ruiz 2007).

Bay of Cádiz. The Bay of Cádiz is a semi-enclosed bay, facing the northeast $\left(325^{\circ}\right)$. It covers 17022 ha which are mostly surrounded by natural $(25.7 \%)$ and dried (34.2\%) marshes, salt ponds $(32.4 \%)$ and urban areas $(7.7 \%)$. The tidal regime is semidiurnal, with a mean tidal range of $2 \mathrm{~m}$. Water renewal ranges from 13.2 to $37.2 \%$ during neap and spring tides, respectively, taking between 1.5 and $4 \mathrm{~d}$ to completely exchange the water volume of the external bay. A narrow channel connects 2 distinct sections, the inner bay (1313 ha) to the south, and the outer bay (8032 ha) to the north (Barragán et al. 1996) (Fig. 1). In the inner bay, tides are the main factor driving water currents, decreasing in speed towards the south. In the outer bay, an increasing influence of tides has been observed from the north (very low) to the south (very high), close to the channel connecting both sections (Sánchez-Lamadrid et al. 2002).

Fieldwork and laboratory procedures. Tidal flux at the channel connecting the inner and the outer bay would ensure adequate sampling conditions, but intense shipping traffic makes fieldwork very difficult in this area. However, tidal effects are still very pronounced in different creeks and rivers flowing into the bay. We chose the Guadalete River (Fig. 1) because it was easily accessible and there were suitable pier facilities to deploy our sampling gear. This is a $157 \mathrm{~km}$ long river, with a $220 \mathrm{~m}$ wide river mouth. Sampling took place $1 \mathrm{~km}$ upstream where salinity is always close to that of seawater, except during periods of heavy rainfall.

This study was undertaken during late spring and summer of 2 consecutive years, from 18 July to $26 \mathrm{Sep}$ tember 2006, and from 12 June to 13 September 2007.

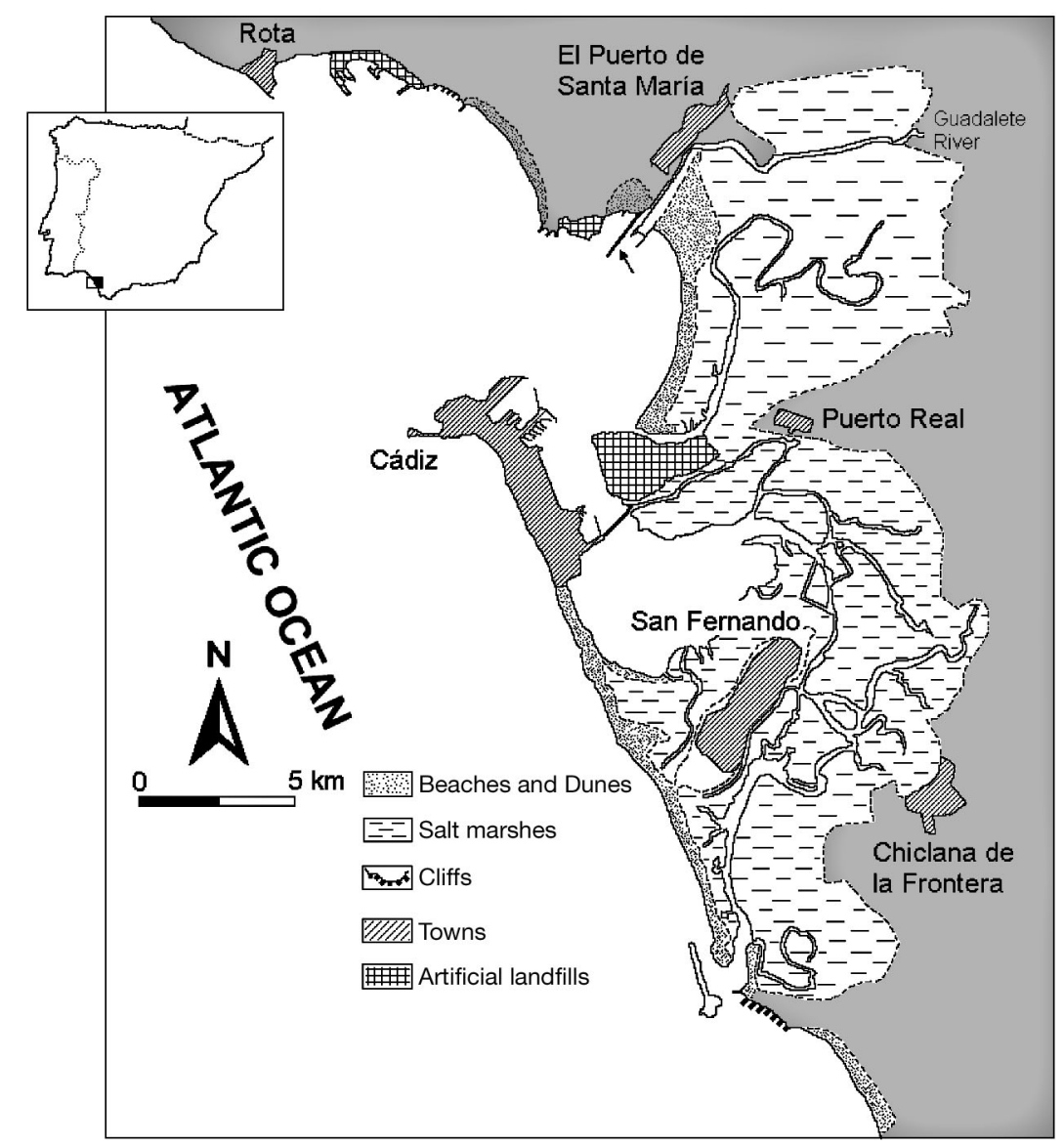

Fig. 1. Study area, including the salt-marsh zones (adapted from Benavente et al. 2000). Arrow points to the location of the sampling nets 
Four plankton nets with a mesh size of $500 \mu \mathrm{m}$ were deployed at a fixed point during the first sampling period to quantify megalopal abundance, flowing both up- and downstream, and at different depths. Two of the nets were positioned facing upstream and other 2 facing downstream. In each orientation, one net was maintained $0.5 \mathrm{~m}$ below the surface and the other one $0.3 \mathrm{~m}$ above the bottom. During the second sampling period, only the nets facing upstream were placed. Vertical distance between nets varied from 5 to $8 \mathrm{~m}$ depending on the tidal cycle. The nets were attached to stainless steel frames anchored from their anterior and posterior ends to avoid being displaced by currents. All nets were specifically designed for filtering only against flow, i.e. nets facing upstream sampled only ebbing tides and those facing downstream only flooding tides (for details, see Queiroga et al. 2006). The nets were raised and rinsed every day to collect the megalopae retained.

Samples taken during the 2006 sampling period were all fixed in $4 \%$ formalin just after collection. The same procedure was undertaken in 2007 for bottom nets, but samples from the surface were maintained in vivo, and immediately transported to the laboratory where megalopae were sorted. Each individual was held separately in glass vials containing filtered seawater $(0.45 \mu \mathrm{m}$ mesh size), collected at the sampling site. Water was changed every day, and megalopae were held unfed. It is possible that food deprivation affected survivorship and molting rate. However, our objective was not to accurately estimate natural physiological conditions in the field, but to compare the competent state among these larvae. As we made sure all individuals were subjected to the same rearing conditions, comparisons should reveal differences among species. Vials were checked daily for the presence of dead megalopae, or exuviae with respective first juveniles, and the time each individual took to die or molt was recorded. We assumed that competence state at the sampling date was inversely proportional to the time to molt. Previous comparisons between time-tomolt and molt-staging estimates of competence state in coastal brachyuran megalopae have shown that they provide discrepant results, the former rendering more consistent results over time and space (Moreira et al. 2007). All specimens were fixed in $4 \%$ formalin and stored for later identification. All megalopae were counted and identified to species or genus when possible, using the specific descriptive literature.

Physical data. To evaluate the likelihood of different transport mechanisms, the time series of megalopae catch for the main taxa were related to those of key physical variables, namely tidal range, wind stress, sea level and salinity. Tidal range data were obtained from the official tide table provided by the Instituto Hidro- gráfico de la Marina (Spain), and daily values computed as the difference between the average of the 2 daily maximum heights, and the average of the 2 daily minimum heights. An offshore seawatch buoy $\left(36^{\circ} 28.8^{\prime} \mathrm{N}, 6^{\circ} 57.6^{\prime} \mathrm{W}\right), \sim 36$ nautical miles from the sampling station, was used to obtain hourly measurements of wind velocity and direction for both sampling periods.

Rather than defining cross- or longshore wind components, multiple directions were tested by projecting wind stress estimates at $15^{\circ}$ axis intervals, starting at 0 to $180^{\circ}$ (north to south) and ending at 165 to $345^{\circ}$. Besides testing whether or not megalopae are transported during the relaxation of upwelling-favorable winds or whether they engage downwind drift, testing the significance of multiple wind directions over different settlement seasons could also explain taxonspecific patterns of onshore transport, even under the same general advective regime. For each direction, wind stress was calculated as (Jorge da Silva 1992):

$$
\left(T_{d}\right)=\rho_{\mathrm{a}} C|\vec{v}| v_{d}
$$

Where $\rho_{\mathrm{a}}$ is the air density $\left(1.12 \mathrm{~kg} \mathrm{~m}^{-3}\right), C$ is the constant drag coefficient $(0.0012), \vec{V}$ is the wind-velocity vector, and $v_{d}$ is the vector component for direction $d$.

Sea level data, provided by the Instituto Español de Oceanografía (Spain), were obtained from the Cádiz harbor gauge, located $7 \mathrm{~km}$ from our sampling site. We used a $15 \mathrm{~min}$ frequency dataset, and filled missing gaps by interpolation, which comprised 9.17 and $5.13 \%$ of all records during the first and second sampling periods, respectively. The software Tidex, developed by the Department of Applied Physics of the University of Cádiz (Spain), was used to obtain predicted tidal values at the study area, at the same sampling frequency. The residual sea level (RSL) was calculated as the difference between observed and predicted tidal values. Wind stress, salinity and RSL data were averaged to obtain daily values.

Statistical analyses. Tide and wind effects on larval supply: The time series of megalopal supply included only the average data from the 2 nets facing downstream, sampling flooding tides. Prior to statistical analyses, abundance data were $\log (x+1)$-transformed to stabilize the variance and reduce the influence of large peaks. The time series were first subjected to spectral analyses (Rayner 1971) to identify their harmonic components. Their significance was assessed by testing whether periodogram values follow the expected exponential distribution, predicted in white-noise series, using the Kolmogorov-Smirnov 1-sample procedure (Rohlf \& Sokal 1981, Sokal \& Rohlf 1995). Crosscorrelations were tested between different physical and biological variables to (1) assess the relationship 
between tidal amplitude and the supply of megalopae, (2) allow the identification of forcing mechanisms promoting sea level anomalies inside the Bay of Cádiz, and (3) evaluate the association between RSL and megalopae abundance. For all time series, autocorrelation functions were checked for temporal dependence of data. In most cases, $\log$ transformation $(x+1)$ or differencing $\left(x_{t}-x_{t-1}, t=\right.$ time), was enough to remove autocorrelation, but in the case of tidal amplitude and megalopae abundance for all 3 species, a white-noise series could not be obtained by these means. In order to avoid underestimating Type I errors in correlations involving these latter variables, standard errors were corrected accordingly (Box et al. 1994), before computing $t$ statistics. In all cases, correlations were tested up to a lag of $5 \mathrm{~d}$.

The strong correlation found between tidal range and megalopae supply, for all 3 species, suggests that this first variable may largely mask the effect of wind stress on the coastward advection of megalopae. To investigate the possible influence of wind on the onshore supply of megalopae, the data was first treated to remove the tidal signal. This was accomplished by fitting a least squares regression model to supply data for each species, using wind stress and a set of sine and cosine functions describing the semilunar cycle of tidal range as independent variables, following the procedure used by Queiroga et al. (2006). The components of wind vectors were calculated for the 12 axis orientations mentioned above. As megalopae onshore supply might respond to discrete wind events with a delay of several days, but also to the cumulative wind forcing over similar periods, multiple regression models were adjusted to identify effects of wind stress, at any given direction, for time lags ranging from 0 to $5 \mathrm{~d}$, and for time windows spanning from 1 to $4 \mathrm{~d}$, so that intervals including the effect of winds lagging more than $5 \mathrm{~d}$ behind were not tested. This procedure, based on the protocols of Paula et al. (2001) and Queiroga (2003), was adopted in this study to assess the wind strength needed to detect settlement pulses and to roughly estimate offshore distance of larval pools. Therefore, for each reference axis and species, we tested the significance of 18 regression models. The adjusted model for the referred multiple regression analysis is:

$$
\begin{aligned}
& \operatorname{Meg}_{d}= \\
& a_{0}+\sum_{i=1}^{7} a_{i} \cos \left(\frac{2 \pi i d}{14}\right)+\sum_{i=1}^{6} b_{i} \sin \left(\frac{2 \pi i d}{14}\right)+c_{1} \tau_{w}+e_{d}
\end{aligned}
$$

Where Meg is the average daily megalopal abundance, $d$ is the day of the year, $\tau_{w}$ is the average daily wind stress in a given direction, $a_{0}$ to $a_{7}, b_{1}$ to $b_{6}$ and $c_{1}$ are regression coefficients, $e_{d}$ is the random error term and $i$ is an integer dummy variable that generates the periodic components ( $i$ runs from 1 to 7 in the case of cosine functions, and from 1 to 6 in the case of sine functions, since the sine of multiples of $\pi$ is zero). The tidal range effect was set as $14 \mathrm{~d}$, because spectral analysis evidenced a strong component matching this period in time series of megalopal supply. The standard regression coefficient assessed the relative importance of the explanatory variables included in the regression equation. As a correlation structure was observed in residuals due to a high autocorrelation of megalopal supply, the standard regression coefficient had to be adjusted. This was done by replacing the sum of squares of residuals by the sum of squares of the white-noise sequence produced by the adjustment of an autoregressive process to the residuals.

In order to verify whether the different species examined responded to a similar wind forcing regime, and if such a condition is persistent among seasons (2006 to 2007), we recorded the wind directions at which correlation coefficients at the shortest lags were highest and statistically significant, and calculated the average difference among such directions $(\mathrm{n}=5$, Brachynotus sexdentatus 2006, 2007; Nepinnotheres pinnotheres 2006, 2007; Panopeus africanus 2006). We then built the expected frequencies distribution for the average angle differences if wind orientation varied randomly. For this, averages were calculated for 1000 sets of random directions $(n=5)$. The average value which cumulated $5 \%$ of this expected distribution was the critical value to either hold the null hypothesis of unrelated responses to wind forcing, or accept that these crab species responded to a general wind-driven transport mechanism.

Upstream migration and competence of megalopae: The patterns of reinvasion of the sampled estuary were compared among species, according to the vertical distribution of larvae and to the proportion of individuals undertaking upstream migration. Results were interpreted in the light of average competence of megalopae, estimated at the study site during the 2007 season, and adult habitat as reported in the literature.

The vertical distribution of larvae moving upstream was compared among species and tidal regime by calculating the proportion of megalopae collected at the surface during neap and spring tides. Replicate values were obtained from the pool of individuals collected under a given tidal period. The data were analyzed using a 3-way analysis of variance, in which 'year' (2006, 2007), 'tidal regime' (spring, neap tides) and 'species' (Brachynotus sexdentatus, Nepinnotheres pinnotheres, Panopeus africanus) were considered fixed factors. As the number of tidal periods with valid records was unequal across levels of the tested factors, some data had to be randomly excluded from the 
analysis to achieve balance. Four replicate values were used. Variance homogeneity was verified using Cochran's $C$-test, and post hoc comparisons were conducted using the Student-Newman-Keuls procedure, when needed. As numbers of megalopae moving downstream were much lower, the vertical distribution of this larval pool was only examined according to species. For that, a multi-comparison of proportions (Zar 1999) was carried out using the 2006 data, when downstream nets were placed.

The net flux of megalopae was compared among species for the 2006 season, and was calculated as the amount of megalopae collected in the upstream nets divided by the total catch. Proportions of larvae moving upstream equal to or above 0.5 indicate net upstream migration. We analyzed the data according to 'species' and 'tidal regime', with 4 replicate values. Linear correlations at lag 0 were run in order to verify whether net-flux temporal patterns are coherent among species, and to test whether variations of RSL render some effect on these larvae. Data transformations and correction of standard errors in autocorrelated series were carried out as explained above.

Larval competence was examined in 2 different ways. First, the proportion of megalopae which successfully molted to the juvenile stage was compared among species using the multiple-comparison procedure cited above. For those species with higher molting frequencies (Nepinnotheres pinnotheres and Brachynotus sexdentatus, see Results), the effect of tidal regime was tested by pooling the data within spring and neap tide periods. Proportions of molting individuals in these 2 periods were compared using a 2-tailed $Z$-test. Secondly, the mean molting time was compared between these 2 species using a 2 -tailed $t$-test for heteroscedastic data sets.

\section{RESULTS}

\section{Brachyuran species composition in plankton samples}

The 3 most abundant species, Panopeus africanus, Brachynotus sexdentatus and Nepinnotheres pinnotheres, accounted for $80 \%$ of all brachyuran larvae (Table 1), and were the ones chosen for analyses. Sixteen brachyuran groups were identified in samples, including fully estuarine, euryhaline and typical marine taxa, and spanning all the most important superfamilies, namely Xanthoidea, Grapsoidea, Majoidea, Ocypodoidea and Portunoidea, apart from common taxa belonging to minor groups, such as pinnotherids and leucosiids. Such species richness is not surprising because the Bay of Cádiz is one of the most productive areas in the Iberian Peninsula, harboring maximum
Table 1. Overall species composition of brachyuran megalopae obtained during the 2006 and 2007 sampling periods

\begin{tabular}{|lcc|}
\hline \multirow{2}{*}{ Taxon } & \multicolumn{2}{c|}{ Sampling period } \\
& 2006 & 2007 \\
\hline Panopeus africanus & 35.14 & 57.34 \\
Brachynotus sexdentatus & 24.24 & 11.52 \\
Nepinnotheres pinnotheres & 17.43 & 19.25 \\
Ilia nucleus & 8.15 & 1.07 \\
Pilumnus hirtellus & 4.85 & 0.89 \\
Macropodia sp. & 2.18 & 2.71 \\
Uca tangeri & 1.69 & 0.23 \\
Rhithropanopeus harrisi & 1.62 & 2.28 \\
Xantho spp. & 1.12 & 0.43 \\
Parthenope & 0.21 & - \\
Brachynotus atlanticus & 0.14 & - \\
Liocarcinus sp. & - & 3.33 \\
Carcinus maenas & - & 0.16 \\
Pirimela denticulata & - & 0.05 \\
Inachus sp. & - & 0.39 \\
Ebalia sp. & - & 0.02 \\
Not identified & 3.23 & 0.32 \\
& & \\
\hline
\end{tabular}

values of zooplankton abundance and diversity (Drake et al. 1998, González-Gordillo \& Rodríguez 2003).

\section{Tide and wind effects on larval supply}

The time-series of the daily catch of megalopae during both sampling periods showed a clear periodicity related to tidal range and, occasionally, lunar cycle (Figs. 2 \& 3). During the 2006 sampling period, periodograms showed a single peak at $14.0 \mathrm{~d}$ for the 3 studied species $(0.234<d<0.580$; $\mathrm{p}<0.01$ for all species). For the 2007 sampling period, 2 main peaks, at 13.4 and $31.3 \mathrm{~d}$, were significant for Panopeus africanus $(d=0.555 ; \mathrm{p}<0.01)$, and a single peak, at 15.7 d, for both Brachynotus sexdentatus and Nepinnotheres pinnotheres $(\mathrm{p}<0.01 ; d=0.411$ and $d=$ 0.353, respectively). Cross-correlation analyses between tidal range and megalopal catch rendered positive coefficients significant, with maximum values at 0 and $1 \mathrm{~d}$ lags (Table 2, 'tide vs. catch'), supporting a direct effect of tidal range on the supply of megalopae at the study site. The efficiency of these same sampling nets was tested by Queiroga et al. (2006). As mesh size was large, suspended particles never clogged the nets, allowing an apparent constant filtering efficiency over different tidal regimes. Differences in larval supply over the tidal-amplitude cycle, such as those shown in Figs. $2 \& 3$, are much higher than differences in current speed during the same tidal phases, usually not exceeding a 1:2 ratio. This indicates that the larval supply patterns reported herein are not an artifact of varying filtering efficiency over different tidal regimes. 


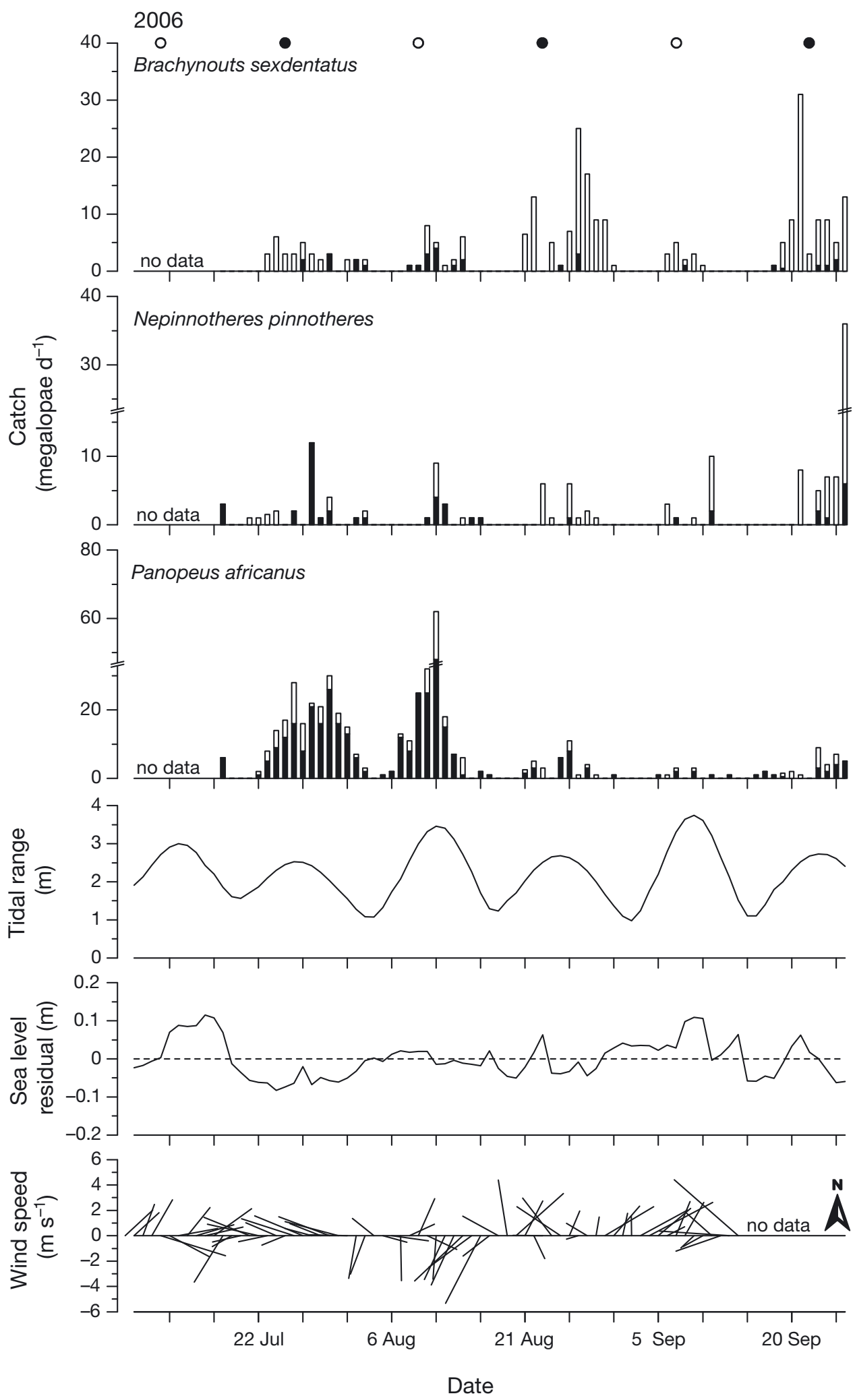

Fig. 2. Brachynotus sexdentatus, Nepinnotheres pinnotheres, and Panopeus africanus. Time series of megalopal catch and relevant physical variables during the 2006 sampling period. Black and white columns in catch series represent bottom and surface numbers of larval frequency, respectively. Vectors in the wind speed plot point to the direction from which winds blew. Dates of full and new moons are indicated at the top of the upper plot 


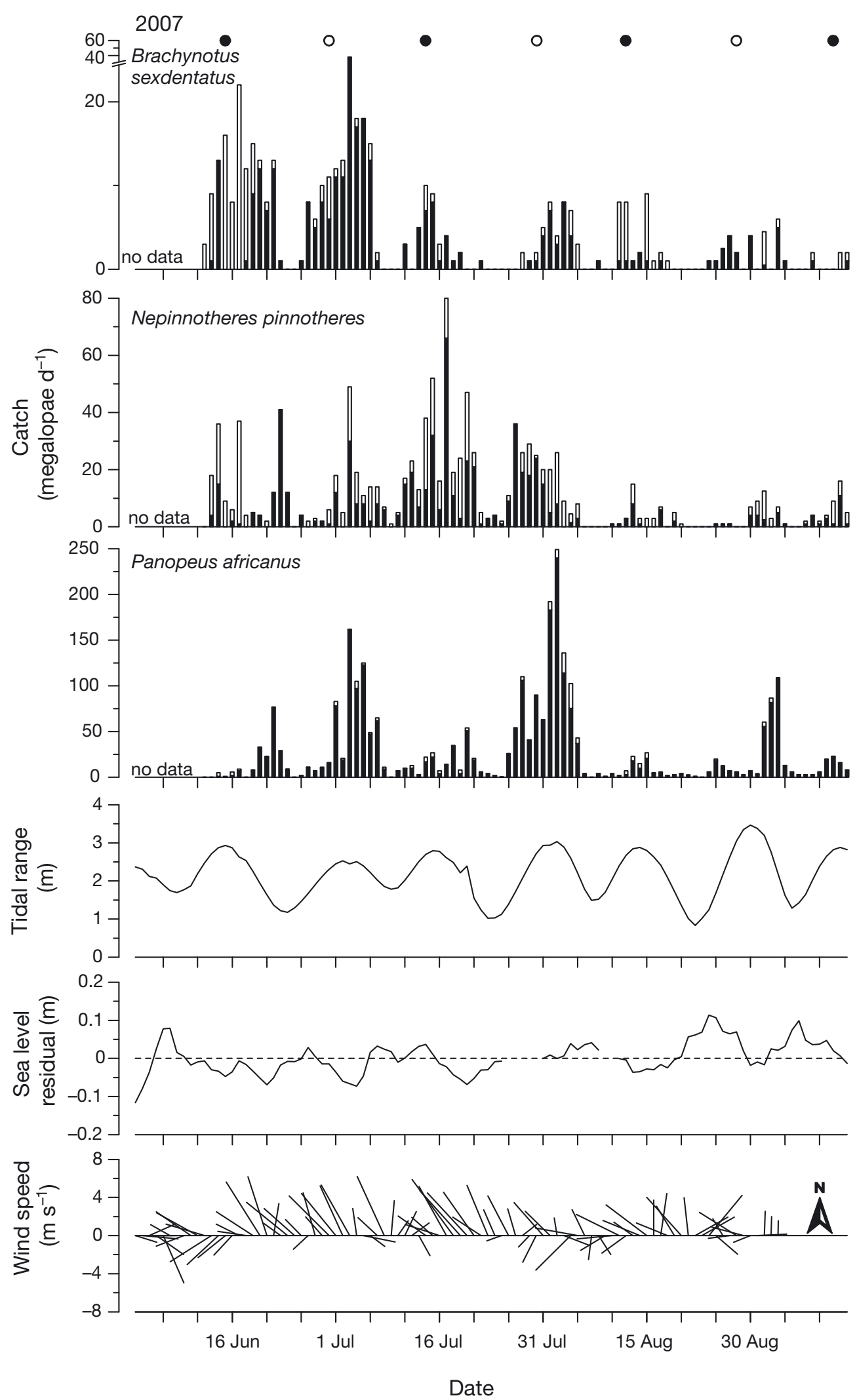

Fig. 3. Brachynotus sexdentatus, Nepinnotheres pinnotheres, and Panopeus africanus. Time series of megalopal catch and relevant physical variables during the 2007 sampling period. Black and white columns in catch series represent bottom and surface numbers of larval frequency, respectively. Vectors in the wind speed plot point to the direction from which winds blew. Dates of full and new moons are indicated at the top of the upper plot 
Table 2. Cross-correlations relating average tidal range and residual sea level (RSL) to megalopal catch for the examined species. For each species and year, only maximum correlation coefficients (r) for statistically significant relationships are shown. Pa: Panopeus africanus; Bs: Brachynotus sexdentatus; Np: Nepinnotheres pinnotheres

\begin{tabular}{|c|c|c|c|c|c|c|}
\hline \multicolumn{4}{|c|}{2006} & \multicolumn{3}{|c|}{2007} \\
\hline $\operatorname{Lag}(d)$ & $\mathrm{Pa}$ & Bs & $\mathrm{Np}$ & $\mathrm{Pa}$ & Bs & $\mathrm{Np}$ \\
\hline \multicolumn{7}{|c|}{ Tide vs. catch } \\
\hline 0 & - & 0.413 & - & - & - & - \\
\hline 1 & - & - & 0.416 & 0.383 & 0.482 & 0.418 \\
\hline \multicolumn{7}{|c|}{ RSL vs. catch } \\
\hline 0 & - & - & - & - & -0.405 & -0.476 \\
\hline 1 & - & -0.391 & - & -0.274 & - & - \\
\hline 2 & -0.293 & - & - & - & - & - \\
\hline
\end{tabular}

The wind regimes recorded in 2006 and 2007 were markedly different. In 2006, wind direction and speed were much more variable (Fig. 2), alternating frequently between westerlies and easterlies. Winds started blowing from the NE, but soon shifted to NW, turning to intense SW until mid-August. During the remainder of this sampling period, winds blew from the $\mathrm{N}$, changing from NW to NE, again turning to strong NW winds at the end. In contrast, strong NW winds prevailed in 2007 (Fig. 3), except for the first $10 \mathrm{~d}$, during which wind speed and intensity were variable, and the last third of the season, when weaker northerlies occurred. Average wind speed and direction were $4.08 \mathrm{~m} \mathrm{~s}^{-1}$ and $284^{\circ}$ in 2006 , and $4.51 \mathrm{~m} \mathrm{~s}^{-1}$ and $306^{\circ}$ in 2007 .

Wind stress influenced RSL at the coast during both sampling periods, as it decreased with westerly and northerly winds and increased with southerlies (Table 3). However, the response of sea level differed according to wind direction. While NW winds, running almost parallel to the coast, rapidly dropped RSL, such an effect is more delayed in the case of $\mathrm{W}$, but mostly SW winds, at which significant relationships were observed at lags up to $5 \mathrm{~d}$. In turn, megalopae catch was inversely related to RSL (Table 2, 'RSL vs. catch'). The time of response of megalopae catch to RSL differed between the sampled years, ranging from 1 to $2 \mathrm{~d}$ in 2006 and 0 to $1 \mathrm{~d}$ in 2007. However, the pattern of response was similar among species. Panopeus africanus lagged 1 more day compared to Brachynotus sexdentatus (2006) or Nepinnotheres pinnotheres $(2006,2007)$.
Table 3. Cross-correlations between wind stress, in all tested directions (Dir; see 'Materials and methods - Physical data'), and residual sea level (RSL). Only correlation coefficients (r) for statistically significant relationships are shown. Bold numbers indicate directions for maximum positive and negative $\mathrm{r}$-values in both years

\begin{tabular}{|lccc|}
\hline \multirow{2}{*}{ Lag $(\mathrm{d})$} & Dir $\left({ }^{\circ}\right)$ & \multicolumn{2}{c|}{ Wind stress vs. RSL } \\
& & 2006 & 2007 \\
\hline $\mathbf{0}$ & $\mathbf{1 8 0}$ & $\mathbf{0 . 2 9 1}$ & $\mathbf{0 . 3 6 4}$ \\
5 & 195 & - & -0.333 \\
4 & 210 & - & -0.432 \\
3 & 225 & - & -0.494 \\
1 & 240 & - & -0.542 \\
1 & 255 & - & -0.590 \\
1 & 270 & - & -0.603 \\
$\mathbf{0}$ & $\mathbf{2 8 5}$ & - & $-\mathbf{0 . 6 0 3}$ \\
0 & 300 & - & -0.597 \\
0 & 315 & -0.274 & -0.579 \\
0 & 330 & -0.313 & -0.545 \\
$\mathbf{0}$ & $\mathbf{3 4 5}$ & $\mathbf{- 0 . 3 2 7}$ & -0.482 \\
\hline
\end{tabular}

For this latter species, there was no effect of RSL on megalopal catch in 2006.

Results of periodic regression models, testing the effect of wind stress on the onshore advection of megalopae, are summarized in Tables 4 \& 5. Significant directions largely correspond to northerly, or, more frequently, westerly winds. Average differences between the most significant wind directions obtained for these species in each of the 2 sampled seasons is small $\left(57^{\circ}\right.$, Fig. 4A), falling within the left $5 \%$ tail of the distribu-

Table 4. Regression analyses showing the effect of wind stress (including all tested directions, lags and time windows) on megalopal catch for the 2006 sampling period. Only correlation coefficients (r) for statistically significant relationships are shown. Bold numbers indicate maximum $r$ values, and respective wind directions (Dir), for each lag tested. See Table 1 for species names in full

\begin{tabular}{|c|c|c|c|c|c|c|c|}
\hline \multirow{2}{*}{$\begin{array}{l}\text { Lag } \\
\text { (d) }\end{array}$} & \multirow{2}{*}{$\begin{array}{l}\text { Window } \\
\text { (d) }\end{array}$} & \multicolumn{2}{|c|}{ B. sexdentatus } & \multicolumn{2}{|c|}{ N. pinnotheres } & \multicolumn{2}{|c|}{ P. africanus } \\
\hline & & $\begin{array}{c}\text { Dir } \\
\left({ }^{\circ}\right)\end{array}$ & $\mathrm{r}$ & $\begin{array}{l}\text { Dir } \\
\left({ }^{\circ}\right)\end{array}$ & $\mathrm{r}$ & $\begin{array}{l}\text { Dir } \\
\left({ }^{\circ}\right)\end{array}$ & $\mathrm{r}$ \\
\hline \multirow[t]{4}{*}{0} & 1 & - & - & - & - & - & - \\
\hline & 2 & $\mathbf{0}$ & 0.534 & - & - & - & - \\
\hline & 3 & - & - & - & - & - & - \\
\hline & 4 & - & - & - & - & - & - \\
\hline \multirow[t]{4}{*}{1} & 1 & 345 & 0.569 & - & - & - & - \\
\hline & 2 & 330 & 0.585 & - & - & - & - \\
\hline & 3 & - & - & - & - & 270 & 0.668 \\
\hline & 4 & - & - & - & - & 255 & 0.665 \\
\hline \multirow[t]{4}{*}{2} & 1 & 330 & 0.555 & - & - & 315 & 0.64 \\
\hline & 2 & - & - & - & - & $240-255$ & 0.679 \\
\hline & 3 & - & - & - & - & $225-240$ & 0.674 \\
\hline & 4 & - & - & - & - & $195-210$ & 0.667 \\
\hline \multirow[t]{3}{*}{3} & 1 & - & - & 270 & 0.423 & 240 & 0.682 \\
\hline & 2 & - & - & 225 & 0.419 & 255 & 0.671 \\
\hline & 3 & - & - & - & - & 180 & 0.667 \\
\hline \multirow[t]{2}{*}{4} & 1 & - & - & 195 & 0.419 & 285 & 0.621 \\
\hline & 2 & - & - & - & - & 195 & 0.63 \\
\hline 5 & 1 & - & - & - & - & 195 & 0.623 \\
\hline
\end{tabular}


tion of frequencies built for expected average differences of random data (Fig. 4B). These results suggest there is a general wind-driven mechanism responsible for the onshore larval transport for all 3 of these

Table 5. Regression analyses showing the effect of wind stress (including all tested directions, lags and time windows) on megalopal catch for the 2007 sampling period. Only correlation coefficients (r) for statistically significant relationships are shown (no results for $P$. africanus were statistically significant). Bold numbers indicate maximum $r$ values, and respective wind directions (Dir), for each lag tested. See Table 1 for species names in full

\begin{tabular}{|lccccc|}
\hline $\begin{array}{l}\text { Lag } \\
(\mathrm{d})\end{array}$ & $\begin{array}{c}\text { Window } \\
(\mathrm{d})\end{array}$ & \multicolumn{2}{c}{$\begin{array}{c}\text { B. sexdentatus } \\
\text { Dir }\end{array}$} & $\mathrm{r}$ & \multicolumn{2}{c|}{$\begin{array}{c}\text { N. pinnotheres } \\
\text { Dir } \\
\left({ }^{\circ}\right)\end{array}$} & $\mathrm{r}$ \\
\hline 0 & & $\left.{ }^{\circ}\right)$ & & & \\
\hline & 1 & 270 & 0.486 & 270 & 0.374 \\
& 2 & $240-285$ & 0.497 & $300-315$ & 0.361 \\
& 3 & 240 & 0.528 & $\mathbf{3 1 5}$ & $\mathbf{0 . 3 7 4}$ \\
& 4 & $\mathbf{2 4 0}$ & $\mathbf{0 . 5 3 7}$ & 300 & 0.369 \\
& 1 & 315 & 0.493 & 0 & 0.343 \\
& 2 & 240 & 0.531 & $\mathbf{3 3 0}$ & $\mathbf{0 . 3 6 1}$ \\
& 3 & 240 & 0.540 & 315 & 0.354 \\
& 4 & $\mathbf{2 4 0}$ & $\mathbf{0 . 5 4 2}$ & - & - \\
2 & 1 & 240 & 0.525 & $\mathbf{3 0 0 - 3 1 5}$ & $\mathbf{0 . 3 5 2}$ \\
& 2 & 240 & 0.532 & 285 & 0.350 \\
& 3 & 240 & 0.534 & $285-300$ & 0.347 \\
3 & 4 & $\mathbf{2 4 0}$ & $\mathbf{0 . 5 4 4}$ & - & - \\
& 1 & 255,330 & 0.491 & - & - \\
& 2 & $\mathbf{2 7 0 - 2 8 5}$ & $\mathbf{0 . 5 0 3}$ & - & - \\
4 & 3 & 255 & 0.518 & - & - \\
& 1 & 330 & 0.495 & - & - \\
5 & 2 & $\mathbf{2 7 0}$ & $\mathbf{0 . 5 0 9}$ & - & - \\
& 1 & $\mathbf{2 7 0 - 2 8 5}$ & $\mathbf{0 . 5 0 2}$ & - & - \\
\hline
\end{tabular}

A

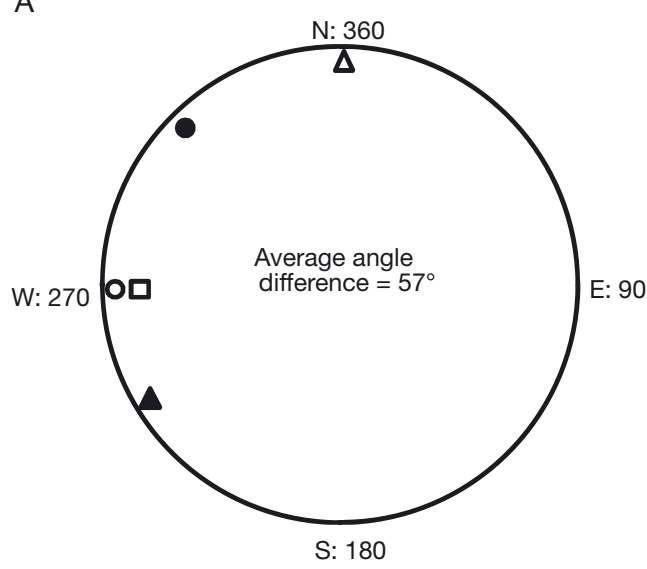

$\Delta$ Brachynotus 2006
O Nepinnotheres 2006
$\square$ Panopeus 2006

Arachynotus 2007

Nepinnotheres 2007 brachyuran species. There were, however, subtle differences in wind directions among species and between sampled seasons. During the 2006 sampling period (Table 4), the catch of Brachynotus sexdentatus megalopae increased quickly ( 0 to $2 \mathrm{~d}$ ) in response to $\mathrm{N}-\mathrm{NW}$ winds, for cumulative windows of 1 and $2 \mathrm{~d}$. On the other hand, Nepinnotheres pinnotheres and Panopeus africanus responded to W-SW winds, although more slowly, with a lag of $3 \mathrm{~d}$. The rapid response of $B$. sexdentatus suggests that N-NW winds, which directly face the entrance to the Bay of Cádiz, are more efficient in transporting larvae to bay waters than $\mathrm{W}$ or SW winds. In most cases, stronger wind effects were verified at short cumulative windows, probably due to the higher frequency of wind direction shifts observed during this season. P. africanus responded exceptionally to a larger cumulative window after a lag of 1 to $3 \mathrm{~d}$.

Results for the 2007 sampling period (Table 5) provided further support for the effect of westerlies, but 2 important differences were verified. (1) Exact directions at which relationships presented higher correlation coefficients changed for these species. Brachynotus sexdentatus was now brought onshore by SW winds, Nepinnotheres pinnotheres by NW, and Panopeus africanus was not affected by wind stress at all. (2) The response of larval supply under the prevalence of strong NW winds was now slower for $B$. sexdentatus ( 0 to $5 \mathrm{~d}$ ), with higher effects over larger windows (up to $4 \mathrm{~d}$ ), but more rapid for $N$. pinnotheres ( 0 to $2 \mathrm{~d}$ ),
B

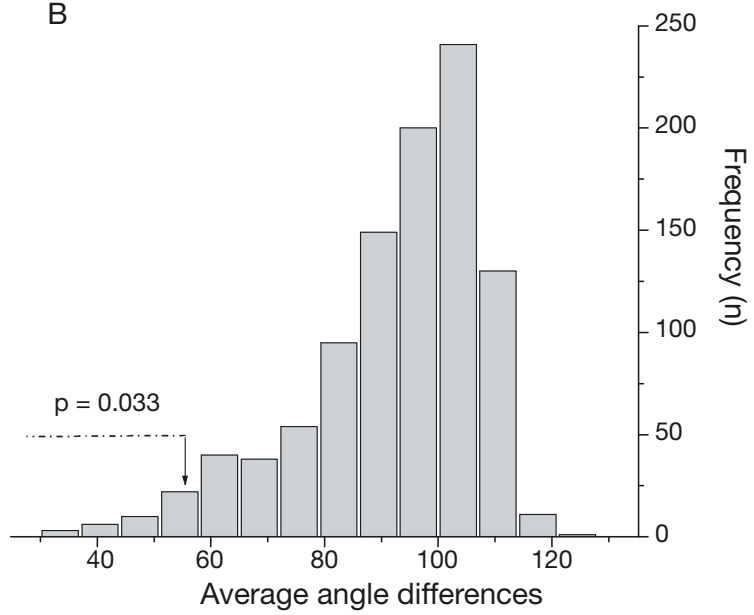

Fig. 4. Brachynotus sexdentatus, Nepinnotheres pinnotheres, and Panopeus africanus. (A) Schematic representation of most significant wind directions associated with larval transport, showing a predominance of northwesterlies, and (B) expected frequency distribution of average angle differences built for random data, indicating the location of the average difference of $57^{\circ}$, which accounts for the variation of wind significant forcing in the study species during the 2006 and 2007 sample seasons. N: North, 
with higher correlation coefficients at windows of 1 to $3 \mathrm{~d}$. Again, this suggests a more rapid response when winds blew from NW.

Even when the exact relationship between wind and abundance differs between years, the wind directions at which correlations are significant mostly coincide with that prevailing during that year, as also reported in similar studies (Ogburn et al. 2009). Overall interannual differences of megalopal supply were evaluated by comparing equivalent portions of time-series, with the same date interval (July 18 to September 13) and number of spring tides $(n=4)$. Supply increased 5.4and 13.0-fold from 2006 to 2007 for Panopeus africanus and Nepinnotheres pinnotheres, but decreased $35 \%$ in the case of Brachynotus sexdentatus.

\section{Upstream migration and competence of megalopae}

At the sampled estuarine site, average salinity $( \pm \mathrm{SD})$ was close to that of seawater $(31.4 \pm 1.9)$ and, therefore, the results hereafter must be interpreted as behavioral responses to saline rather than brackish water.

The vertical distribution of megalopae moving upstream differed among species and between sampling years, but not between spring and neap tides, nor any of the interactions of main effects $(C=0.266, \mathrm{p}>0.05)$ (Table 6). The proportion of megalopae collected at the surface was similar for Brachynotus sexdentatus and Nepinnotheres pinnotheres, and lower for Panopeus africanus (Fig. 5A). This difference is consistent across sampled years, despite a very large interannual difference. Surprisingly, the overall proportion of surface megalopae more than doubled from 2006 to 2007 (Figs. 2, 3 \& 5B). The vertical distribution of megalopae moving up- and downstream follows a similar trend, be-

Table 6. 3-way analysis of variance testing differences in the vertical distribution of larvae moving upstream, measured as the proportion of megalopae collected at surface, according to 'species', 'year' and 'tidal regime'. C: Cochran's test statistic

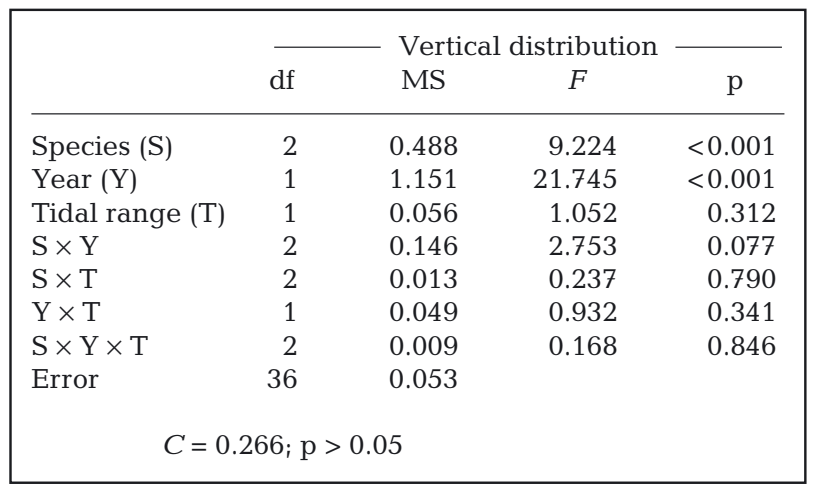

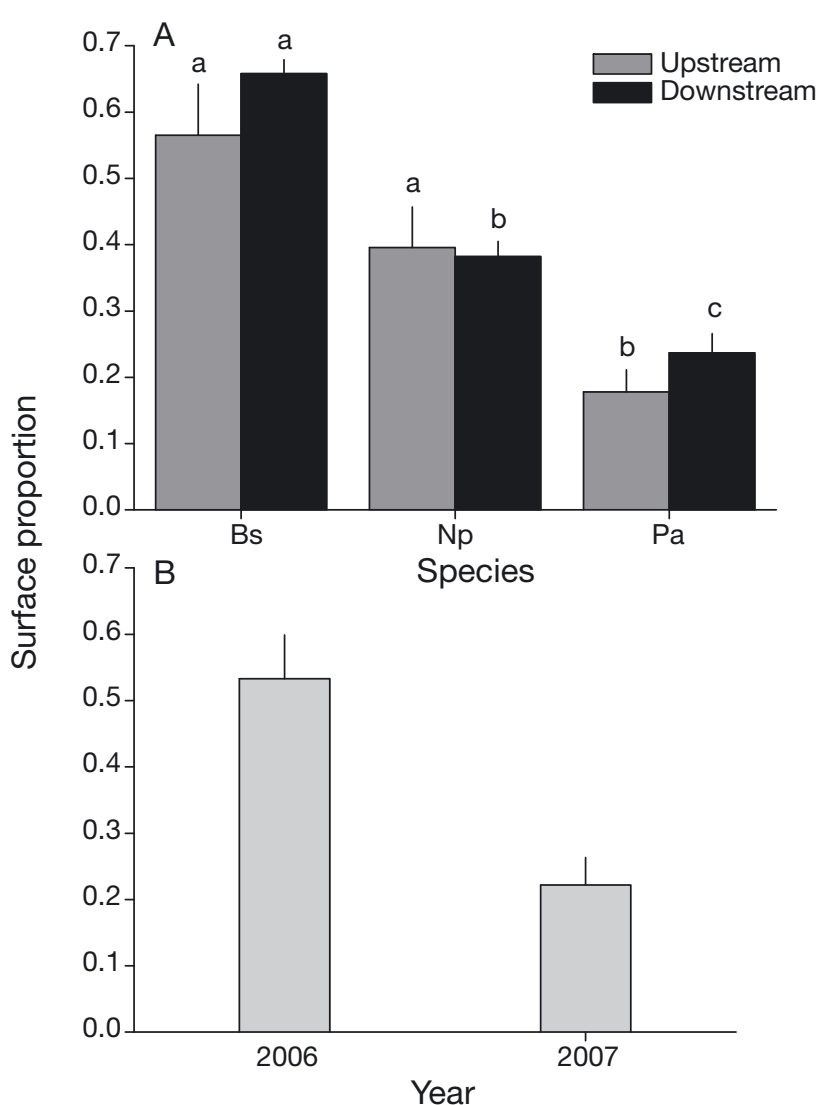

Fig. 5. Brachynotus sexdentatus (Bs), Nepinnotheres pinnotheres (Np), and Panopeus africanus (Pa). Vertical distribution of megalopae at the Guadalete River estuary. (A) Proportion of megalopae caught at surface for each species for upand downstream transport. Matching letters above bars indicate lack of statistical differences ( $p>0.05$ ), within upstream (Student-Newman-Keuls comparisons of means) and downstream (multiple comparison of proportions) data sets. (B) Inter-annual variation. In all cases, whiskers $=\mathrm{SE}$

sides the significant difference between $B$. sexdentatus and $N$. pinnotheres in the latter.

For all 3 species, net flux of megalopae was upstream. However, there were differences between all species, regardless of tidal regime $(C=2.701, \mathrm{p}>0.05)$ (Fig. 6 , Table 7). The proportion of Panopeus africanus megalopae collected in upstream-facing nets was the highest, followed by Nepinnotheres pinnotheres, and Brachynotus sexdentatus, of which less than $70 \%$ were larvae moving upstream. The temporal net-flux patterns over the 2006 series were neither coherent between species, because correlations were all non-significant, nor associated with RSL, as expected under the effect of wind forcing within the bay ( $p>0.05$ in all cases).

Larvae of these 3 species also differed considerably in their competency level at the Guadalete River. Very few Panopeus africanus larvae metamorphosed suc- 


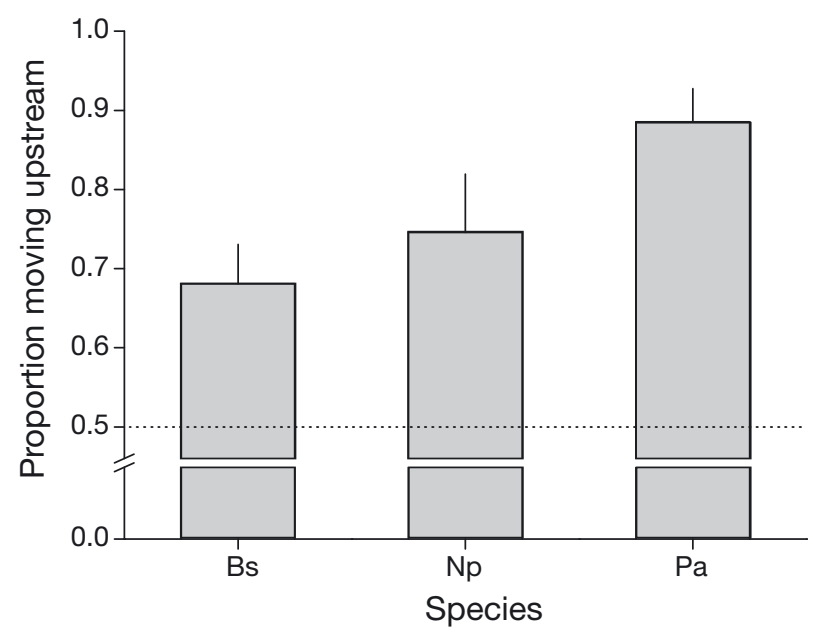

Fig. 6. Brachynotus sexdentatus (Bs), Nepinnotheres pinnotheres ( $\mathrm{Np})$, and Panopeus africanus $(\mathrm{Pa})$. Net-flux of megalopae at Guadalete River estuary. Average proportion of larvae moving upstream. Net upstream transport is expected for values above the dotted line. Whiskers $=\mathrm{SE}$. Statistical differences were significant for all between-species comparisons (multiple comparison of proportions; $\mathrm{p}<0.05$ )

Table 7. 2-way analysis of variance testing differences of net flux, measured as proportion of megalopae moving upstream, according to 'species' and 'tidal regime'. C: Cochran's test statistic

\begin{tabular}{|lccrr|}
\hline & \multicolumn{4}{c}{ Net flux } \\
\cline { 2 - 5 } & df & MS & $F$ & \multicolumn{1}{c|}{$\mathrm{p}$} \\
\hline Tidal regime (T) & 1 & 0.013 & 0.560 & 0.464 \\
Species (S) & 2 & 0.087 & 3.700 & $<0.050$ \\
T $\times$ S & 2 & 0.052 & 2.203 & 0.139 \\
Error & 18 & 0.024 & & \\
\multicolumn{4}{r}{$C=2.701 ; \mathrm{p}>0.05$} \\
\hline
\end{tabular}

cessfully to the first crab stage, while nearly half of the collected Brachynotus sexdentatus megalopae were capable of molting and almost all Nepinnotheres pinnotheres did so (Fig. 7). For the last 2 species, which molted frequently in the laboratory, the proportion of molting specimens was not related to the tidal conditions (spring vs. neap periods) when megalopae were collected $(\mathrm{p}>0.05 ; Z=0.53$ and $Z=0.52$ for $B$. sexdentatus and $N$. pinnotheres, respectively). Frequency distributions of the time megalopae took to molt varied substantially between these 2 species (Fig. 8). In both cases, right-skewed distributions were observed, but the pre-molt average time differed significantly between them (Student's $t$-test: $t_{s}=9.87 ; \mathrm{p}<0.0001$ ), being much lower for $N$. pinnotheres $(1.99 \mathrm{~d})$ than for B. sexdentatus ( $3.83 \mathrm{~d})$.

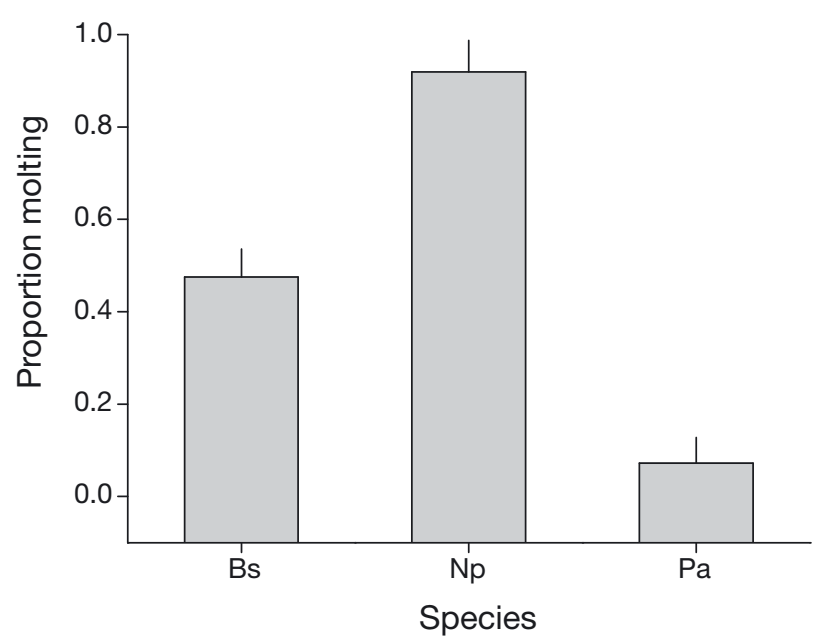

Fig. 7. Brachynotus sexdentatus (Bs), Nepinnotheres pinnotheres $(\mathrm{Np})$, and Panopeus africanus $(\mathrm{Pa})$. Competence of megalopae at the Guadalete River estuary. Average proportion of larvae molting to the first crab stage. Whiskers $=$ SE. Statistical differences were significant for all between-species comparisons (multiple comparison of proportions; $\mathrm{p}<0.05$ )

\section{DISCUSSION}

\section{Shelf and coastal transport}

Tide and wind effects on the supply of megalopae were generally similar for all 3 species examined, thus indicating a general pattern for late-stage larvae of coastal brachyuran species. As expected, larval catch was maximum at times of highest tidal amplitude. Megalopal supply spanned 2 orders of magnitude over the tidal cycle, suggesting that behavioral responses of larvae to increased high tide hydrostatic pressure (often with a $1 \mathrm{~d}$ delay), besides the fortnightly variation in tidal current speeds, determines the temporal variation of larval delivery in this estuarine system. This closely resembles the results obtained for the estuarine brachyurans Callinectes sapidus and Carcinus maenas (Epifanio et al. 1984, Goodrich et al. 1989, van Montfrans et al. 1990, Queiroga et al. 2006).

Longshore wind forcing from the north (2006) or northwest (2007) rapidly decreased sea level while the opposite was observed for southerly winds, thus indicating upwelling and downwelling events, respectively, in accordance to the patterns detailed by García-Lafuente \& Ruiz (2007). Wind effects on megalopal supply were contrary to what could be expected. In general, winds blowing in nearly onshore directions were positively correlated to larval supply with a short delay. There was no positive effect in response to the relaxation of upwelling-favorable winds or their reversal, as predicted. West and northwest wind forc- 


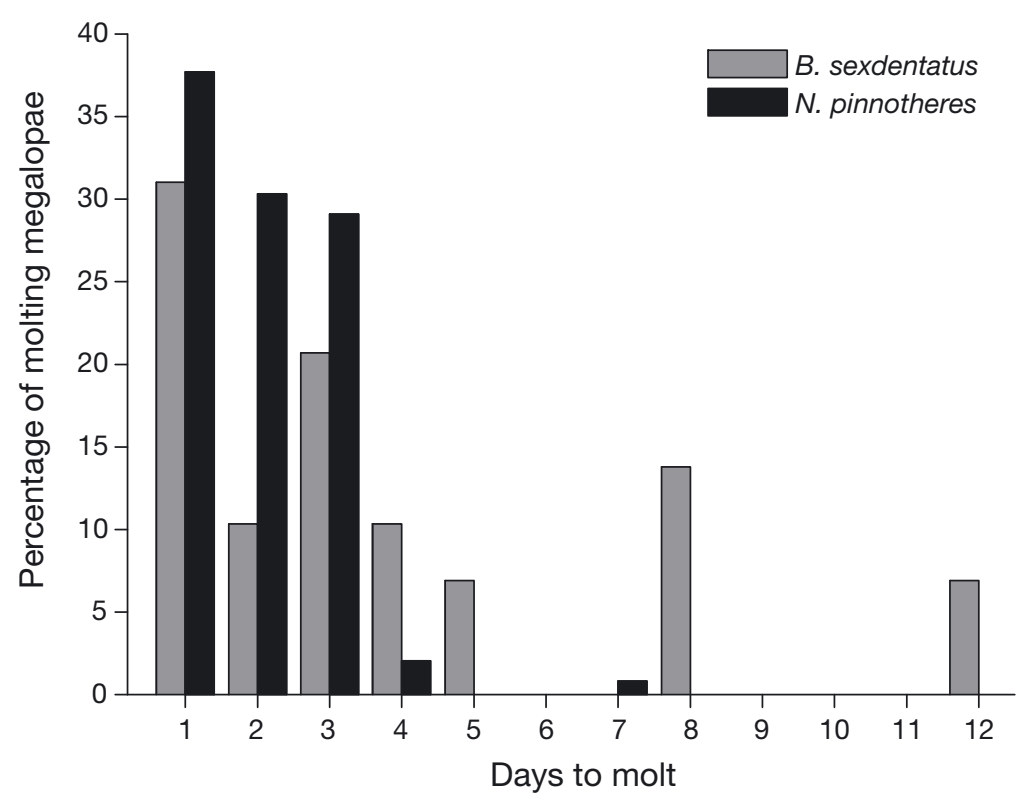

Fig. 8. Brachynotus sexdentatus and Nepinnotheres pinnotheres. Competence of megalopae at the Guadalete River estuary. Frequency distributions of the time (d) megalopae of took to molt in the laboratory

ing also caused upwelling and offshore movement of sub-surface water masses, which did not prevent onshore advection of megalopae.

Shelf topography and larval behavior are the best candidates for explaining the patterns observed. Late larvae of these species are mostly concentrated in surface and very shallow waters (authors' unpubl. data). As wind effects were generally observed at very short time lags, the source larval pools are likely to have been relatively close to shore. If the bulk of larvae remain within an offshore distance of $10 \mathrm{~km}$ from the sampling site, and within 40 to $50 \mathrm{~km}$ a few $\mathrm{km}$ north, megalopae will stay in inner shelf waters. Therefore, the depth layer where these larvae are thought to be concentrated, even if some sort of vertical migration takes place, may not be subjected to extensive Ekman transport, but prone to downwind drift (Huang 1979, Bakun 1996) heading to the east or southeast.

During the 2006 season, Nepinnotheres pinnotheres and Panopeus africanus drifted eastwards, nearly matching the direction of average winds, but the former was advected to the southeast in 2007, when prevailing winds also shifted towards this direction. At least for $N$. pinnotheres, the drift path apparently depends on the predominant forcing conditions, and larvae are likely to be regularly available both offshore, at the front of the sampling site, and at locations situated further north. This should not apply to Brachynotus sexdentatus. In this species, megalopal supply responded to northwest wind stress in 2006, but in 2007 the drift pattern moved, reacting to the stress of westerlies. Also, overall megalopal catch decreased to nearly one third of the 2006 total catch in this species, in contrast to the other 2 brachyurans, in which larval supply increased 5 to 13 times, and wind effects extended over longer time lags. Altogether, these results suggest that an important $B$. sexdentatus larval pool coming from the north decreased from 2006 to 2007, and that megalopal supply during the second sampled season originated from a more distant pool, almost directly offshore of the sampling site.

The increase in larval supply for Nepinnotheres pinnotheres and Panopeus africanus from 2006 to 2007 may be explained by the directional shift in predominant winds. At the mesoscale, winds blowing from the west affect the whole eastern gyre of GoC, hampering the eastward flow of the warm coastal countercurrent, thus confining shallow-water plankton assemblages to the eastern gyre of GoC (García-Lafuente \& Ruiz 2007), now circulating near the mouth of the Bay of Cádiz. At a more local scale, including our sampling area, major oceanographic features are still unknown. Wind-driven circulation patterns have, however, been reported in detail for other similar estuarine systems. In general, longshore remote forcing over the shelf, which causes coastal sea-level fluctuations, is responsible for depth-independent flow across bay inlets, while local along-estuary forcing produces direct stress over the surface, producing bi-directional flows, i.e. a downwind current near the surface and a flow in the opposite direction below (Officer 1976). In spite of the importance of remote forcing, local wind stress can be very significant (Wong \& Moses-Hall 1998, Janzen $\&$ Wong 2002). Therefore, westerly winds may (1) concentrate a surface larval pool at the entrance of the Bay of Cádiz, and (2) transport these larvae into the bay, assuming that ocean-bay exchange follows the pattern above. Under such a wind regime, $P$. africanus larvae may be actually retained in bay waters, explaining the lack of significance of wind stress in its transport, at any of the lags tested, during the 2007 season. The larval pool may have been simply too close, and therefore the transport too limited to be detected in a daily time series. However, tidally driven processes might alter wind-driven patterns of larval supply. Ogburn et al. (2009) showed that estuarine abundance of Callinectes sapidus megalopae is positively correlated to downwelling events, onshore winds and the duration of nighttime flood tides. While wind effects showed a regular reported pattern of supply, the duration of night- 
time flood tides sometimes explained more than 50\% of the abundance variability. Ogburn et al. (2009) observed that wind-driven transport, if strong enough, could modify the pattern of supply expected from the duration of nighttime flood tides, despite the nocturnal flood transport being sufficient for ingress of an available larval pool. The increased abundance of $P$. africanus during the time when no correlation was found between wind and its supply might be explained by the duration of nighttime flood tides.

Larval transport processes may be coherent over spatial scales from tens (Lagos et al. 2007) to hundreds (Diehl et al. 2007) of $\mathrm{km}$ for different coastal organisms, and the likely mechanisms we discuss herein may apply to other coastal areas along the southwestern coast of the Iberian Peninsula. However, independent results are lacking and, therefore, support for the mechanisms proposed is still awaited. Significant advance may be achieved once the shelf distribution patterns of early and late stage larvae are described, a task which is currently in progress.

\section{Estuarine transport and competence state}

Once in the estuary, late larvae of species with contrasting life histories are expected to follow different behavioral and physiological patterns. As our sampling site is still under the influence of seawater salinity, the species assemblage recorded is very heterogeneous, composed of estuarine, coastal and euryhaline species, as already observed by González-Gordillo \& Rodríguez (2003). The numbers of megalopae are well distributed among these 3 groups $(40.6,25.7$ and $33.7 \%$, respectively) and each of the 3 most important species belongs to a different one of these groups. The mud crab Panopeus africanus is a typical estuarine species (Manning \& Holthuis 1981), usually found buried or under stones (Rodríguez et al. 1997). All larval stages have been found along an estuary in southeastern Portugal, suggesting a retention strategy (Paula 1993), but, close to our sampling site, megalopae appeared to reinvade estuarine waters during nocturnal floods (GonzálezGordillo et al. 2003). The pea crab Nepinnotheres pinnotheres may be found associated with polychaetes and echinoderms (Christensen \& McDermott 1958, Stevens 1990), but mostly as a commensal of the bivalves Scrobicularia plana and Cerastoderma glaucum when inside the Bay of Cádiz, following its host distribution over a variety of coastal habitats, mostly over sheltered areas (J. Cuesta pers. comm.). The varunid Brachynotus sexdentatus is a euryhaline species, collected at several coastal sites from the mid intertidal zone, to a depth of no more than $1 \mathrm{~m}$ (Froglia \& Manning 1978, d'Udekem d'Acoz 1999), but also occurring in estuarine waters, up to several $\mathrm{km}$ upstream (our own observations).

Combined, the parameters measured in this study (vertical distribution, net upstream flux and larval competency) provided a basis to assess the potential along-estuary distribution of early benthic stages. The vertical distribution of upstream- and downstreammoving larvae was the same, and therefore should be viewed basically as a proxy of potential horizontal transport, since current speed decreases exponentially from the surface to the bottom due to friction (Vogel 1994). As Brachynotus sexdentatus (can) and Panopeus africanus (should) colonize areas far upstream, we expected to observe megalopae of these species mostly at the surface, compared to those of Nepinnotheres pinnotheres, which were already in suitable habitat to settle. We also expected that net flux should reflect the extent to which these species rely on selective tidal stream transport (STST) to reach adequate habitat. $B$. sexdentatus and $N$. pinnotheres are both littoral species; the former apparently more opportunistic, forming dense populations in different habitats over a wide salinity range and likely to show little dependence on upstream transport, while the latter seems more restricted to shallow nearshore areas and was expected to show some net flux. $P$. africanus is only found in typical estuarine areas and should rely heavily on STST. Finally, if megalopae respond to nearby cues to develop into competent stages, and such response is higher for species with a more specific habitat niche, one could conceive a decreasing trend in larval competency from $N$. pinnotheres to $P$. africanus. Our results exactly match expectations, except for the vertical distribution patterns. We found $P$. africanus closer to the bottom than $N$. pinnotheres.

Species-independent interannual differences in vertical distribution of megalopae in the Guadalete River were very large, suggesting that long-standing physical processes in the water column may deeply affect the advection potential of late larvae entering coastal areas. Yet, lack of information on the oceanography of the Bay of Cádiz, and especially on the Guadalete River, prevents us from drawing any conclusions on possible mechanisms ruling depth distribution of these larvae. It is very likely that such differences are also related to the above-mentioned change in the wind regime from 2006 to 2007, but the attempts below to interpret this result remain speculative. In 2006, larvae were distributed almost evenly along the water column, but in 2007 they were clearly more concentrated near the bottom. These situations could be expected in mixed and stratified estuarine conditions, respectively. Along-estuary winds are often correlated with mixing, but winds blowing towards the higher estuary may eventually cause stratification due to the accumulation 
of less dense surface water upstream (Vázquez et al. 1994), in our case due to heating during diurnal ebbing tides (García-Lafuente et al. 2006) rather than rainfall. Westerly winds prevailing in 2007 could lead to stratification in a similar way, thus making it difficult for megalopae to ascend. Alternatively, decreased RSL in 2007 due to the action of upwelling-favorable winds might translate into a hydrostatic pressure below response thresholds in megalopae, reducing the swimming capacity during the flooding phase of the tidal cycle. As a result, megalopae would concentrate close to the bottom as observed. It is also possible that other environmental factors, not monitored in this study, such as temperature or physiological state of larvae, affect the behavior of these megalopal stages. As horizontal transport depends extensively on vertical migration, identifying the processes affecting larval behavior is an important task.

Acknowledgements. The authors thank the Club Náutico del Puerto de Santa María for kindly giving us access to field facilities during the busy summer months. We also thank Puertos del Estado, Agencia Estatal de Metereología and the Instituto Español de Oceanografía (IEO) for providing the wind and RSL data used in this study, and the research project P06-RNM-01637 from the Junta de Andalucia. We are indebted to E. Reyes, from the Department of Applied Physics of the University of Cádiz, Spain, for her extraordinary help, advice and patience with the TIDEX software. This study would be impossible without the altruistic and truthful attitude of undergraduate students of the Marine Sciences major at the University of Cádiz, who assisted in both fieldwork and laboratory sorting. The manuscript was greatly improved after addressing the comments of 3 anonymous referees. The Ministerio de Ciencia e Innovación (MICINN) supported a Ramón y Cajal contract to J.I.G-G. and a PhD grant to A.O.OF. (BES-2006-13434). This work is part of the research project 'Transporte y reclutamiento larvario de crustáceos bentónicos litorales: importancia de los agentes forzadores costeros y régimen mareal' (CTM2005-00024/MAR) co-financed by the MICINN and FEDER European Funds.

\section{LITERATURE CITED}

Armsworth PR (2002) Recruitment limitation, population regulation, and larval connectivity in reef fish metapopulations. Ecology 83:1092-1104

Bakun A (1996) Patterns in the ocean. Ocean processes and marine population dynamics. California Sea Grant College system - National Oceanic and Atmospheric Administration and Centro de Investigaciones Biológicas del Noroeste, La Paz

Barragán JM, Arias AM, Tejedor M, Bruno M and others (1996) Estudios para la ordenación, planificación y gestión integradas de las zonas húmedas de la Bahía de Cádiz. Oikos-Tau, University of Cádiz (editorial)

Basch LV, Pearse JS (1996) Consequences of larval feeding environment for settlement and metamorphosis of a temperate echinoderm. Oceanol Acta 19:273-285

Benavente J, Gracia FJ, López-Aguayo F (2000) Empirical model of morphodynamic beachface behaviour for lowenergy mesotidal environments. Mar Geol 167:375-390
Bilton DT, Paula J, Bishop JDD (2002) Dispersal, genetic differentiation and speciation in estuarine organisms. Estuar Coast Shelf Sci 55:937-952

Box GEP, Jenkins GM, Reinse GC (1994) Time series analysis: forecasting and control. Prentice-Hall International, Upper Saddle River, New Jersey

Caley MJ, Carr MH, Hixon MA, Hughes TP, Jones GP, Menge BA (1996) Recruitment and the local dynamics of open marine populations. Annu Rev Ecol Syst 27:477-500

Carr MH (1994) Effects of macroalgal dynamics on recruitment of a temperate reef fish. Ecology 75:1320-1333

Christensen AM, McDermott JJ (1958) Life history and biology of the oyster crab Pinnotheres ostreum Say. Biol Bull 114:146-179

Connolly SR, Menge BA, Roughgarden J (2001) A latitudinal gradient in recruitment of intertidal invertebrates in the northeast Pacific Ocean. Ecology 82:1799-1813

Criado-Aldeanueva F, García-Lafuente J, Vargas JM, Del Río J, Vázquez A, Reul A, Sánchez A (2006) Distribution and circulation of water masses in the Gulf of Cádiz from in situ observations. Deep-Sea Res II 53:1144-1160

d'Udekem d'Acoz (1999) Inventaire et distribution des crustacés décapodes de l'Atlantique nord-oriental, de la Méditerranée et des eaux continentales adjacentes au nord de $25^{\circ} \mathrm{N}$. Collection Patrimoines Naturels. MNHN, Paris

> Diehl JM, Toonen RJ, Botsford LW (2007) Spatial variability of recruitment in the sand crab Emerita analoga throughout California in relation to wind-driven currents. Mar Ecol Prog Ser 350:1-17

> Drake P, Arias AM, Rodríguez A (1998) Seasonal and tidal abundance patterns of decapod crustacean larvae in a shallow inlet (SW Spain). J Plankton Res 20:585-601

Eggleston DB, Armstrong DA (1995) Presettlement and postsettlement determinants of estuarine Dungeness crab recruitment. Ecol Monogr 65:193-216

Epifanio CE, Valenti CC, Pembroke AE (1984) Dispersal and recruitment of blue crab larvae in Delaware Bay, USA. Estuar Coast Shelf Sci 18:1-12

Epifanio CE, Little KT, Rowe PM (1988) Dispersal and recruitment of fiddler crab larvae in the Delaware River estuary. Mar Ecol Prog Ser 43:181-188

Farrell TM, Bracher D, Roughgarden J (1991) Cross-shelf transport causes recruitment to intertidal populations in central California. Limnol Oceanogr 36:279-288

- Flores AAV, Cruz J, Paula J (2002) Temporal and spatial patterns of settlement of brachyuran crab megalopae at a rocky coast in Central Portugal. Mar Ecol Prog Ser 229: $207-220$

Forward RB, Tankersley RA (2001) Selective tidal-stream transport of marine animals. Oceanogr Mar Biol Annu Rev 39:305-353

Froglia C, Manning RB (1978) Brachynotus gemmellari (Rizza), the third Mediterranean species of the genus (Crustacea, Decapoda, Brachyura). Proc Biol Soc Wash 91: 691-705

- Gaines S, Roughgarden J (1985) Larval settlement rate: a leading determinant of structure in an ecological community of the marine intertidal zone. Proc Natl Acad Sci USA 82:3707-3711

> García-Lafuente J, Ruiz J (2007) The Gulf of Cádiz pelagic ecosystem: a review. Prog Oceanogr 74:228-251

> García-Lafuente J, Delgado J, Criado-Aldeanueva F, Bruno M, Del Río J, Vargas JM (2006) Water mass circulation on the continental shelf of the Gulf of Cádiz. Deep-Sea Res II 53:1182-1197

González-Gordillo JI, Rodríguez A (2003) Comparative sea- 
sonal and spatial distribution of decapod larvae assemblages in three coastal zones off the south-western Iberian Peninsula. Acta Oecol 24:S219-S233

González-Gordillo JI, Arias AM, Rodríguez A, Drake P (2003) Recruitment patterns of decapod crustacean megalopae in a shallow inlet (SW Spain) related to life history strategies. Estuar Coast Shelf Sci 56:593-607

Goodrich DM, van Montfrans J, Orth JR (1989) Blue crab megalopae influx to Chesapeake Bay: evidence for a wind driven mechanism. Estuar Coast Shelf Sci 29:247-260

Huang NE (1979) On surface drift currents in the ocean. J Fluid Mech 91:191-208

Incze LS, Wahle RA (1991) Recruitment from pelagic to early benthic phase in lobsters Homarus americanus. Mar Ecol Prog Ser 79:77-87

Janzen CD, Wong KC (2002) Wind-forced dynamics at the estuary-shelf interface of a large coastal plain estuary. J Geophys Res 107(C10), 3138 doi: 10.1029/2001JC00059

Jorge da Silva A (1992) Dependence of upwelling related circulation on wind forcing and stratification over the Portuguese northern shelf. ICES CM 1992/C17

Lagos NA, Tapia FJ, Navarrete SA, Castilla JC (2007) Spatial synchrony in the recruitment of intertidal invertebrates along the coast of central Chile. Mar Ecol Prog Ser 350: 29-39

Lamare MD, Barker MF (1999) In situ estimates of larvae development and mortality in the New Zealand sea urchin Evechinus chloroticus (Echinodermata: Echinoidea). Mar Ecol Prog Ser 180:197-211

Manning RB, Holthuis LB (1981) West African brachyuran crabs (Crustacea: Decapoda). Smithson Contrib Zool 306

Marta-Almeida M, Dubert J, Peliz A, Queiroga H (2006) Influence of vertical migration pattern on retention of crab larvae in a seasonal upwelling system. Mar Ecol Prog Ser 307:1-19

McConaugha (1988) Export and reinvasion of larvae as regulators of estuarine decapod populations. Am Fish Soc Symp 3:90-103

> Moreira FT, Harari J, Flores AAV (2007) Neustonic distribution of decapod planktonic stages and competence of brachyuran megalopae in coastal waters. Mar Freshw Res 58:519-530

Morgan SG, Fisher JL, Mace AJ, Akins L, Slaughter AM, Bollens SM (2009) Cross-shelf distributions and recruitment of crab postlarvae in a region of strong upwelling. Mar Ecol Prog Ser 380:173-185

Officer CB (1976) Physical oceanography of estuaries (and associated coastal waters). Wiley, New York

Ogburn MG, Díaz H, Forward RB Jr (2009) Mechanisms regulating estuarine ingress of blue crab Callinectes sapidus megalopae. Mar Ecol Prog Ser 389:181-192

Onitsuka T, Kawamura T, Ohashi S, Iwanaga S, Horri T, Watanabe Y (2010) Effects of delayed metamorphosis and delayed post-settlement feeding on post-larval survival and growth of the abalone Haliotis diversicolor. Aquaculture 298:239-244

Palmer MA, Allan JD, Butman CA (1996) Dispersal as a regional process affecting the local dynamics of marine and stream benthic invertebrates. Trends Ecol Evol 11: 322-326

Paula J (1993) Ecologia da fase larvar e recrutamento de crustáceos decápodes no Estuário do Rio Mira. PhD dissertation, University of Lisbon

> Paula J, Dray T, Queiroga H (2001) Interaction of offshore and inshore processes controlling settlement of brachyuran megalopae in Saco mangrove creek, Inhaca Island (South Mozambique). Mar Ecol Prog Ser 215:251-260
Pechenik JA, Levine SH (2007) Estimates of planktonic larval mortality using the marine gastropods Crepidula fornicata and C. plana. Mar Ecol Prog Ser 344:107-118

Queiroga H (2003) Wind forcing of crab megalopae recruitment to an estuary (Ria de Aveiro) in the northern Portuguese upwelling system. Invertebr Reprod Dev 43: 47-54

Queiroga H, Blanton JO (2005) Interactions between behavior and physical forcing in the control of horizontal transport of decapod crustacean larvae: An overview. Adv Mar Biol 47:107-214

> Queiroga H, Almeida MJ, Alpuim T, Flores AAV and others (2006) Tide and wind control of megalopae supply to estuarine crab populations on the Portuguese west coast. Mar Ecol Prog Ser 307:21-36

Queiroga H, Cruz T, dos Santos A, Dubert J and others (2007) Oceanographic and behavioural processes affecting invertebrate larval dispersal and supply in the western Iberia upwelling ecosystem. Prog Oceanogr 74:174-191

Rabalais NN, Burditt FR Jr, Coen LD, Cole BE and others (1995) Settlement of Callinectes sapidus megalopae on artificial collectors in four Gulf of Mexico estuaries. Bull Mar Sci 57:855-876

Rayner JN (1971) An introduction to spectral analysis. Pion, London

Relvas P, Barton ED (2002) Mesoscale patterns in the Cape São Vicente (Iberian Peninsula) upwelling region. J Geophys Res 107 (C10), 3163 doi:10.1029/2000JC000456

> Rilov G, Dudas SE, Menge BA, Grantham BA, Lubchenco J, Schiel DR (2008) The surf zone: a semi-permeable barrier to onshore recruitment of invertebrate larvae? J Exp Mar Biol Ecol 361:59-74

Rodríguez A, Drake P, Arias AM (1997) Reproductive periods and larval abundance patterns of the crabs Panopeus africanus and Uca tangeri in a shallow inlet (SW Spain). Mar Ecol Prog Ser 149:133-142

Rohlf FJ, Sokal RR (1981) Statistical tables, 2nd edn. WH Freeman and Company, New York

Roughgarden J, Gaines S, Possingham H (1988) Recruitment dynamics in complex life cycles. Science 241:1460-1466

Sánchez R, Mason E, Relvas P, da Silva AJ, Peliz A (2006) On the inner-shelf circulation in the Gulf of Cádiz, southern Portuguese shelf. Deep-Sea Res II 53:1198-1218

Sánchez-Lamadrid A, Jiménez MT, Ruíz JT, Gutiérrez JM and others (2002) Bahía de Cádiz: Protección de los recursos naturales pesqueros y aplicaciones para instalaciones acuícolas. Consejería de Agricultura y Pesca, Junta de Andalucía

Shanks AL (1995) Mechanisms of cross-shelf dispersal of larvae invertebrates and fish. In: McEdward L (ed) Ecology of marine invertebrate larvae. CRC Press, Boca Ratón, FL, pp 323-368

Shanks AL (2006) Mechanisms of cross-shelf transport of crab megalopae inferred from a time series of daily abundance. Mar Biol 148:1383-1398

Shanks AL, Brink L (2005) Upwelling, downwelling, and cross-shelf transport of bivalve larvae: test of a hypothesis. Mar Ecol Prog Ser 302:1-12

Sokal RR, Rohlf FJ (1995) Biometry. WH Freeman and Company, New York

Sponaugle S, Cowen RK, Shanks A, Morgan SG and others (2002) Predicting self-recruitment in marine populations: biophysical correlates and mechanisms. Bull Mar Sci 70: 341-375

Stevens PM (1990) Specificity of host recognition of individuals from different host races of symbiotic pea crabs (Decapoda: Pinnotheridae). J Exp Mar Biol Ecol 143: 193-207 
Strathmann RR, Hughes TP, Kuris AM, Lindeman KC, Morgan SG, Pandolfi JM, Warner RR (2002) Evolution of local recruitment and its consequences for marine populations. Bull Mar Sci 70:377-396

van Montfrans JC, Peery A, Orth RJ (1990) Daily, monthly and annual settlement patterns by Callinectes sapidus and Neopanope sayi megalopae on artificial collectors deployed in the York River, Virginia: 1985-1988. Bull Mar Sci 46:214-229

Vargas JM, García-Lafuente J, Delgado J, Criado-Aldeanueva F (2003) Seasonal and wind induced variability of sea surface temperature patterns in the Gulf of Cádiz. J Mar Syst 38:205-219

Vázquez LZS, Boxhill JL, Harrison TR, Kremer JN, Foreman K

Editorial responsibility: Steven Morgan,

Bodega Bay, California, USA
(1994) The effects of wind speed and direction on stratification and phytoplankton production in an estuary of Waquoit Bay, Massachussets. Biol Bull 187:285-286

Vogel S (1994) Life in moving fluids. Princeton University Press, Princeton, New Jersey

Wong KC, Moses-Hall, JE (1998) On the relative importance of the remote and local wind effects on the subtidal variability in a coastal plain estuary. J Geophys Res Oceans 103:18292-18404

Zar JH (1999) Biostatistical analysis. Prentice Hall, Upper Saddle River, NJ

Zeldis JR, Oldman J, Ballara SL, Richards LA (2005) Physical fluxes, pelagic ecosystem structure, and larval fish in Hauraki Gulf, New Zealand. Can J Fish Aquat Sci 62:593-610

Submitted: September 23, 2009; Accepted: February 27, 2010 Proofs received from author(s): June 1, 2010 